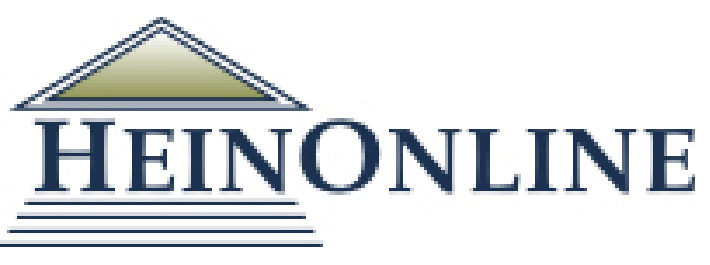

Content downloaded/printed from

HeinOnline

Mon Oct 7 08:24:58 2019

Citations:

Bluebook 20th ed.

Rebecca Amollo, Revisiting the Trips Regime: Rwanda-Canadian ARV Drug Deal Tests the WTO General Council Decision, 17 Afr. J. Int'l \& Comp. L. 240 (2009).

ALWD 6th ed.

Rebecca Amollo, Revisiting the Trips Regime: Rwanda-Canadian ARV Drug Deal Tests the WTO General Council Decision, 17 Afr. J. Int'I \& Comp. L. 240 (2009).

APA 6th ed.

Amollo, R. (2009). Revisiting the trips regime: Rwanda-canadian arv drug deal tests the wto general council decision. African Journal of International and Comparative Law, 17(2), 240-269.

Chicago 7th ed.

Rebecca Amollo, "Revisiting the Trips Regime: Rwanda-Canadian ARV Drug Deal Tests the WTO General Council Decision," African Journal of International and Comparative Law 17, no. 2 (2009): 240-269

McGill Guide 9th ed.

Rebecca Amollo, "Revisiting the Trips Regime: Rwanda-Canadian ARV Drug Deal Tests the WTO General Council Decision" (2009) 17:2 African J of Intl \& Comparative L 240.

MLA 8th ed.

Amollo, Rebecca. "Revisiting the Trips Regime: Rwanda-Canadian ARV Drug Deal Tests the WTO General Council Decision." African Journal of International and Comparative Law, vol. 17, no. 2, 2009, p. 240-269. HeinOnline.

OSCOLA 4th ed.

Rebecca Amollo, 'Revisiting the Trips Regime: Rwanda-Canadian ARV Drug Deal Tests the WTO General Council Decision' (2009) 17 Afr J Int'I \& Comp L 240

-- Your use of this HeinOnline PDF indicates your acceptance of HeinOnline's Terms and Conditions of the license agreement available at https://heinonline.org/HOL/License

-- The search text of this PDF is generated from uncorrected OCR text.

-- To obtain permission to use this article beyond the scope of your license, please use: Copyright Information

Use QR Code reader to send PDF to your smartphone or tablet device 


\title{
REVISITING THE TRIPS REGIME: RWANDA-CANADIAN ARV DRUG DEAL 'TESTS' THE WTO GENERAL COUNCIL DECISION
}

\author{
REBECCA AMOLLO*
}

On 17 July 2007, the world was awakened to Rwanda's notification of the World Trade Organisation's (WTO) Council for Trade-Related Aspects of Intellectual Property Rights (TRIPS) that it plans to import the HIV-drug TriAvir from Canada's giant pharmaceuticals company, Apotex. Two months later, Canada issued a compulsory licence allowing Apotex to use nine patented inventions for manufacturing and exporting TriAvir to Rwanda. On 4 October 2007, Canada notified the Council for TRIPS of the compulsory licence. In September 2008, Apotex said it will ship seven million antiretroviral pills to Rwanda to treat 21,000 patients. Against this backdrop, this article uses the Rwandan-Canadian drug deal to examine the utility of the WTO General Council Decision in making ARV drugs more accessible to Low and Middle Income Countries so far. In doing so, the article's analyses rely on the regime of the Canadian Access to Medicines Regime which was enacted after the WTO Decision. The author discusses some of the issues arising from the deal in light of the effectiveness of the General Council Decision in solving the problem of access to antiretroviral drugs within the right to health and HIV/AIDS context. The article also raises questions relating to the willingness of developing countries to take benefit of the TRIPS flexibilities and the obligation of developed countries to ensure that the flexibilities become a reality.

\section{INTRODUCTION}

When Rwanda announced its intention to import generic drugs from Canada, Stephen Lewis, had this to say:

This is a significant step...Forgetting all the negotiations and shenanigans over the last few years, we can begin to save lives. That is what is crucial. ${ }^{1}$

* Doctoral Candidate, University of the Western Cape, Faculty of Law, Community Law Centre. Email: ramollo@uwc.ac.za. The author would like to thank Dr Lilian Chenwi and Siyambonga Heleba for comments on the paper.

1 Medical News Today, 'GSK Gives Consent to Canadian Drug Company to Manufacture Generic Antiretroviral For Rwanda'. Available at http://www.medicalnewstoday.com/articles/79445.php. Stephen Lewis is the former United Nations Special Envoy for HIV and Aids in Africa. 17 July 2007. Accessed 21 August 2008. 
He also said elsewhere:

The logjam has been broken ... by the government of Rwanda's request for the Canadian generic drug. It is very dramatic and very important because the dream of this legislation ... was that it would save lives. That's what it was all about, that Canada would produce the generic drugs that would allow countries to keep their citizens alive. ${ }^{2}$

The saying goes that if one cannot invent, at least one can copy. For many sub Saharan countries, copying technologies for producing antiretroviral treatment (ARVs) remains a distant aspiration. Africa constitutes about 10 per cent of the world's population but is home to over 70 per cent of the people living with HIV. ${ }^{3}$ In 2006, it was estimated that approximately 2 million people were reported to have lost their lives as a result of HIV/AIDS related illness. ${ }^{4}$ Women have been the worst hit by the epidemic, constituting about 50 per cent of the world infection rate and about 60 per cent of the total rate in Africa. ${ }^{5}$ In many African countries, access to treatment and care for people living with HIV remains a great challenge. Of the approximately 4.6 million people in need of treatment, only about 23 per cent of them are receiving it in the region. ${ }^{6}$ The problem is not limited to HIV/AIDS alone. Other diseases such as tuberculosis and malaria continue to pose great threats to lives on the continent.

There is a stark disparity in access to pharmaceutical products between developed and developing countries. Developing countries make up approximately 80 per cent of the world's population but only represent approximately 20 per cent of global pharmaceutical consumption. ${ }^{7}$ Transnational corporations own approximately 90 per cent of technology and product patents in the world, and up to 80 per cent of technology and product patents in developing countries. This persisting inequity has been attributed to lack of resources, skill inadequacy, market failures, high drug costs, weak or corrupt institutions, government failures and income differences. ${ }^{8}$ All these factors combined result in less than effective pharmaceutical purchasing and distribution systems thus impeding availability of ARVs. One of the issues attending accessibility to ARVs within the context of many sub Saharan countries is the intellectual property regime. The regime of the Trade Related Aspects of Intellectual Property Rights (TRIPS) Agreement has been widely criticised for further impeding access to ARVs. ${ }^{9}$

2 M. Rimmer, 'Race against Time: The Export of Essential Medicines to Rwanda' Public Health Ethics (2008): 89-103: 14.

3 UNAIDS, Report on the Global AIDS Epidemic (Geneva, UNAIDS 2008).

4 Ibid.

5 lbid.

6 Ibid.

7 J. C. Cohen, M. Gyansa-Lutterodt, K. Torpey, L. C. Esmail and G. Kurokawa, 'TRIPS, the Doha Declaration and Increasing Access to Medicines: Policy Options for Ghana', Globalization and Health (2005): 1-17.

8 M. R. Reich, 'The Global Drug Gap', 287 Science (2000): 1979-81.

9 The TRIPS Agreement is Annex 1C of the Marrakesh Agreement Establishing the World Trade Organisation, signed in Marrakesh, Morocco, on 15 April 1994. 
Availability within the context of HIV/AIDS has been argued to entail life saving drugs, procurement strategies of ARVs, and financing the extending initiatives. ${ }^{10}$ The point has been advanced in the same vein that failure to innovate, transfer technology, produce, procure and import drugs are some of the major barriers attributed to availability of medicines. ${ }^{11}$ It has further been argued that improving and sustaining access to antiretroviral treatment (ARVs) by people living with HIV/AIDS (PLWHAs) is a practical way to strengthen HIV prevention, care, treatment and support. This position has received support from several circles including at the international human rights law level where the UN Committee on Economic, Social and Cultural Rights (CESCR Committee), the body charged with the responsibility of interpreting and monitoring the treaty, has elucidated on what access to medicines means within the right to health. ${ }^{12}$ This will be dealt with later in this paper. Against this backdrop, this paper argues, inter alia, that since most countries in the sub Sahara continent are not yet able to produce ARVs locally, at the very minimum, states must make effort to procure their availability to their citizens. This duty is accompanied by the obligation of the international community to cooperate in this bid. This paper uses the recent Rwanda-Canadian drug deal to illustrate some of the issues surrounding this bid, especially under the WTO TRIPS system. The paper highlights some of the issues arising from the deal that could be considered in assessing the utility of the WTO Decision in making ARVs more accessible to Medium and Low Incomes Countries (LMICs), especially those in sub Saharan Africa. Some of the critical questions arising within this debate include: without the capacity to produce ARVs, what should a sub-continent threatened by an epidemic do in order to make available AIDS drugs? Does the Canadian Access to Medicines Regime represent a beacon of hope in this regard? Do the TRIPS regime and its subsequent modifications offer any real solutions to least developed countries particularly in sub Saharan Africa? The paper concludes that the WTO system is neither expeditious, nor a solution because of the unnecessary rigours accompanying its procedures. In the same vein, the paper critiques the Canadian Access to Medicines law, and makes some recommendations in that regard.

\section{ACCESS TO ARVS: THE DUTY TO PRODUCE AND PROCURE AS A COMPONENT OF THE RIGHT TO HEALTH}

The right to health has been dogged with definitional difficulty. Historically, health care systems were developed on a curative or clinical model of health. However,

10 D. Mushayavanhu 'The Realisation of Access to HIV and AIDS-Related Medicines in Southern African Countries: Possibilities and actual Realisation of International Law Obligations', in F. Viljoen and S. Precious (eds), Human Rights Under Threat: Four Perspectives on HIV, AIDS and the Law in Southern Africa, PULP (2007), p. 127.

11 ibid.

12 See General Comment 14 2000, 'The Right to the Highest Attainable Standard of Health' (art. 12 of the Covenant) UN Committee on Economic, Social and cultural Rights. Twenty-Second session), U.N. Doc. E/C.12/2000/4 (2000). 
recently, advances in epidemiological research have sensitised policy and law makers to the importance of public health interventions and preventive strategies of health promotion. ${ }^{13}$ It can however be argued that such definitional problems attend all human rights and particularly those affirming economic, social and cultural human rights. Different terms have therefore been used to describe rights concerning health care. ${ }^{14}$ The terms 'right to health', 'right to health protection' or ' right to health care' have all been advanced as sufficiently conveying the notion of entitlement to the protection of health and the provision of heath care under international law and domestic legal systems. ${ }^{15}$ This paper however does not seek to delve into the debate of the appropriateness of terminology. The paper uses the 'right to health' phraseology.

A human rights perspective of access to AIDS drugs would locate it in the right to health, although it can relate closely to other rights like the right to life. ${ }^{16}$ This is especially so because human rights norms have been argued to set broad standards for the obligations of countries with regard to realising the citizen's human rights. ${ }^{17}$ In this regard, Yamin notes:

Human rights law not only offers an alternative paradigm for understanding issues relating to the availability and distribution of medications, it also provides a workable framework for influencing the way in which adjudicative and legislative bodies, as well as other actors, make decisions that affect access to medications. The right to health could mean, among many things including availability of treatment for opportunistic infections to which they are subject because of the failure of their immune system as a result of HIV infection. It could also mean availability of health facilities which are

13 See generally, A. R. Chapman and S. Russell (eds), Core Obligations: Building a Framework for Economic, Social and Cultural Rights, Intersentia (2002).

14 B. Toebes The Right to Health as a Human Right in International law, Intersentia (1998); B. Toebes The Right to Health in International Law, Intersentia-Hart (1999), pp. 22-4; B. Toebes 'Towards an improved understanding of the international human right to health', 21 Human Rights Quarterly (1999): 661-3 in C. Ngwena and R. J. Cook, 'Rights Concerning Health', in D. Brand and C. H. Heyns (eds), Socio Economic Rights in South Africa, Pretoria University Law Press (2005). See a criticism of a 'right to health' as opposed to a 'right to health care' in R. Macklin, Against Relativism: Cultural Diversity and the Search for Ethical Universals in Medicine, Oxford University Press (1999), p. 235.

15 There appears to be no necessary conflict between the terms 'right to health', 'right to health protection' or 'right to health care'. Proponents of the terms 'right to health' or 'right to health care' or 'right to health protection' have argued that these terms are more accurate and more realistic than 'right to health' in that health itself can not be guaranteed. They argue that, at best, the state can provide diagnostic, preventive, curative and rehabilitative services for the attainment of health. See also R. Roemer, 'The Right to Health Care', in H. L. Fuenzalida-Puelma and S. S. Connor (eds), The Right to Health in the Americas: A Comparative Constitutional Study, Pan American Health Organization (1989), pp. 17-23; H. Hannum, 'The UDHR in National and International Law', 3 Health and Human Rights (1998): 145, 153.

16 C. Onyemelukwe, 'Access to Anti-retroviral Drugs as a Component of the Right to Health in International Law: Examining the Application of the Right in Nigerian Jurisprudence', 7 African Human Rights Law Journal (2007): 446, 448.

17 Z. Lazarinni, 'Access to HIV Drugs: Are we Changing the Two World Paradigm?', 17 Connecticut Journal of International Law (2002): 281, 288. 
necessary, especially for those who can no longer benefit substantially from the sole treatment of opportunistic infections. ${ }^{18}$

The right to health is provided for in most international treaties. The earliest modern human rights instrument - the Universal Declaration of Human Rights (hereafter referred to as the UDHR), proclaims the right to health: ${ }^{19}$ the International Covenant on Economic Social Cultural Rights (hereafter referred to as the ICESCR) further contains a provision that has been lauded as the most important provision for the realisation of the right to health. ${ }^{20}$ It provides for the right to the highest attainable standard of physical and mental health; ${ }^{21}$ the Convention on the Elimination of All Forms of Discrimination Against Women (CEDAW) also provides for the right to health; ${ }^{22}$ the Convention on the Rights of the Child (CRC); ${ }^{23}$ and other authoritative consensus documents. ${ }^{24}$

Like all other human rights, the right to health imposes on countries the obligations to respect, protect, and fulfill this right. ${ }^{25}$ As stated above the CESCR has interpreted the right to health as precisely relating to several elements namely, availability, and accessibility, acceptability and quality. ${ }^{26}$ The Committee explained that 'availability' requires that the public health care facilities, goods and services be available in sufficient quantity. ${ }^{27}$ 'Accessibility' has the overlapping dimensions of non-discrimination, physical accessibility, economic accessibility and information accessibility. ${ }^{28}$ The accessibility principle involves

18 Y. E. Yamin, 'Not just a Tragedy: Access to Medications as a Right under International Law', 21 Boston University International Law Journal (2003): 325, 327. See also H. Watchirs, 'A Human Rights Approach to HIV/AIDS: Transforming International Obligations into National Laws', 22 Australian Yearbook of International Law (2002): 77, 79-80.

19 See Art. 25 of the Universal Declaration. It was adopted and proclaimed by the UN General Assembly in resolution 217 A (III) of 10 December 1948 at Paris.

20 A. R. Chapman, 'Core Obligations Related to the Right to Health and their Relevance for South Africa ', in D. Brand and S. Russell (eds), Exploring the Core Content of Socio-economic Rights: South African and International Perspectives (2003), p. 40.

21 Art. 12 of the CESCR.

22 Art. 12. The Convention on the Elimination of All Forms of Discrimination against Women. 1979; UN document A/34/36.

23 Art. 24. The CRC was adopted by the UN General Assembly on 20 November 1989. It entered into force on 2 September 1990.

24 Notably the UN International Conference on Population and Development, held in Cairo, 5-13 September 1994; Fourth World Conference on Women, Beijing, China, 4-15 September 1995;UN Millennium Development Goals, available at www.un.org/milleniumgoals (accessed 11 July 2006). See Goal 8 on AIDS. For the human rights aspects of the MDGs, see P. Alston, 'Ships Passing in the Night: The Current State of the Human Rights and Development Debate seen through the Lens of the Millennium Goals', 6 Human Rights Quarterly (2005): 755-829; The Heads of State and Government and Representatives of States and Governments assembled at the UN for a special session of the General Assembly. The session adopted the Declaration of Commitment on HIV/AIDS. This took place from 25 to 27 June 2001. This was in accordance with Resolution 55/13.

25 Supra note 12 , para 33.

26 Supra note 12, paras 12 (a-d); T. Barnett and A. Whiteside, AIDS in the Twenty-first Century: Disease and Globalisation Palgrave Macmillan (2002).

27 Supra note 12, para 12 (a).

28 Supra note 12, para 12 (b). 
affordability and thus requires countries to provide what may be necessary for the enjoyment of the right to health for people who cannot afford to provide it for themselves. It has been suggested in this regard that it is obligatory for countries to put in place health insurance schemes to enable their citizens to pay for health services. ${ }^{29}$ This is particularly crucial in developing countries where affordability is largely non existent. It has therefore been suggested that it is necessary to take steps to the extent possible to provide free ARVs for those who cannot afford to pay for them and to subsidise other costs associated with anti-retroviral treatment. It also requires that health facilities should be accessible to all parts of the country. ${ }^{30}$ 'Quality' ensures cultural acceptability, scientific and medically appropriateness of health facilities, goods and services, and good quality. ${ }^{31}$

The obligation to provide health care also relates to the minimum core which in this case would be the obligation to provide accessible ARVs as an essential medicine. ${ }^{32}$ The 'essential medicines' concept prioritises a limited list of vital and essential drugs that are supposed to be effective, safe, good quality and affordable for treating 'the priority health care needs of the population' ${ }^{33}$ About the minimum core concept, Bilchitz argues that its 'principle' relates to 'minimum essential levels of the right'. According to Bilchitz, it refers to the minimum basic resources that are necessary to allow individuals to be free from threat to their survival and to achieve a minimal level of well being. ${ }^{34}$ 'The core is the minimum essential level of health that states have priority obligations to provide' and below which a state should not fall. ${ }^{35}$ Bilchitz argues that in relation to health care, the imposition of such an obligation would involve not only primary health care, but also the provision of expensive drugs that are necessary to preserve life. This can be argued to include the obligation to provide ARVs. It is important to note that the minimum core standard requires that the services should be made available on demand as contrasted with the 'progressive realisation' standard which is spread over time as determined by the availability of resources.

In particular consideration of the hurdles posed by pharmaceutical patents, for example insufficient manufacturing capacity and failure to innovate, amongst

29 Onyemelukwe, supra note 16.

30 This would involve ensuring that rural areas have health facilities which PLWHA living in rural areas can easily access. The quality principle states amongst other things that the right to health includes the provision of unexpired drugs as well as trained health personnel. Countries would therefore have to monitor the proper administration and utilisation of ARVs provided to PLWHA.

31 This requires, inter alia, skilled medical personnel, scientifically approved and unexpired drugs and hospital equipment, safe and potable water, and adequate sanitation. See note 12 above, para 12 (d).

32 Supra note 12, para 43. See also D. Bilchitz, 'The Right to Health Care Services and the Minimum Core: Disentangling the Principled and Pragmatic Strands', 7 ESR Review (2006): 2; Pierre de Vos, 'Access to Anti-retroviral Drugs post-Grootboom' 3 ESR Review (2002): 22; S. Khoza, 'Reducing Mother-to-Child Transmission of HIV: The Nevirapine Case', 3 ESR Review (2002): 2.

33 WHO, 'Essential Medicines', http://www.who.int/essential_medicines/en/ (accessed 15 July 2008).

34 Bilchitz, supra note 32, p. 2.

35 L. Foreman, 'The Imperative to Treat: The South African State's Constitutional Obligations to Provide Antiretroviral Medicines', http://www.ualberta.ca (accessed 12 June 2008). 
others, ${ }^{36}$ the obligation to make HIV/AIDS drugs available would refer to the need for countries to take legislative steps to ensure that developing countries benefit from agreements in international trade organisations, such as the World Trade Organisation (WTO), which allow for public health exceptions to intellectual property rules, thus allowing for the manufacture, exportation and importation of cheaper generic versions or calls upon developed countries to assist resource-poor developing countries in ensuring that their actions as members of international organisations take into consideration the right to health. ${ }^{37}$ It is against this obligation that Canada enacted an Access to Medicines law in 2004. This law is discussed later in this paper.

Besides the inextricable link between access to ARVs and the right to health, it has been argued that eliminating the obstacles which may impede access to and the delivery of ARVs in developing countries is also necessary for the full enjoyment of the right to health. ${ }^{38}$ Hosseinipour et al argue that the interpretation of the right to health to include the underlying determinants of health would mean that countries have obligations under the right to health to deal with the political, economic and health structures obstacles which may prevent access to ARVs, including the inadequacy of a health infrastructure, the non-availability of trained medical professionals, particularly in rural areas, and inequitable resources distribution. $^{39}$

Although categorised as 'soft law' the Declaration of Commitment on HIV/AIDS, adopted by the General Assembly, also recognises that access to ARVs is fundamental to realising the right to health of People Living With HIV/AIDS (PLWHA) and is an essential part of the efforts by countries to combat the epidemic:

Recognising that access to medication in the context of pandemics such as HIV/AIDS is one of the fundamental elements to achieve progressively the full realization of the right of everyone to the

36 For more on these barriers, see, generally, P. Cullet, 'Patents and Medicines: The Relationship between TRIPS and the Human Right to Health', 79 International Affairs (2003): 107-38; B. Loff and M. Heywood, 'Patents on Drugs: Manufacturing Capacity or Advancing Health?', 30 Journal of Law, Medicine and Ethics (2002): 621. See also M. Berger, 'Tripping over Patents: AIDS, Access to Treatment and the Manufacturing of Scarcity', 17 Connecticut Journal of International Law (2002): 157.

37 Art. 8. See also art. 15 of the Declaration of Commitment on HIV/AIDS UNGA ResA/Res/S 26/2).

38 Onyemelukwe, supra note 16, p. 60.

39 M. C. Hosseinipour, P. N. Kazembe, I. M. Sanne and C. M. van der Horst, Challenges in Delivering Anti-retroviral Treatment in Resource-poor Countries (2002), 16 (Suppl. 4) AIDS S178; S. S. Abdool Karim, Q. Abdool Karim, G. Friedland, U. Lalloo and W. M. El Sadr, Implementing Anti-retroviral Therapy in Resource-constrained Settings: Opportunities and Challenges in Integrating HIV and Tuberculosis Care (2004) 18 AIDS 975; UNAIDS, Report on the Global AIDS Epidemic, UNAIDS (2004); C. Webb 'AIDS: The Real Problem is Getting the Medicine out', International Herald Tribune 14 July 2004; see also the case of Minister of Health and Others $v$ Treatment Action Campaign and Others, Case CCT 8/02, where the court required the state to make human resources available, including the provision of counselling facilities. 
enjoyment of the highest attainable standard of physical and mental health. ${ }^{40}$

This has been argued to indicate that countries recognise, at least in principle, the danger that HIV/AIDS poses to societies in developing countries and the role that anti-retroviral treatment can play in mitigating such danger. ${ }^{41}$ Like most soft law instruments which are not intended to be legally binding, the Declaration reflects a good faith commitment and a desire to influence the actual practice of countries. ${ }^{42}$ It can therefore be seen as reflecting the desire of countries to provide access to ARVs (amongst other things), and as a tool to encourage governments to act in response to the need for wide access to ARVs in developing countries. ${ }^{43}$

The Office of the UN High Commission for Human Rights (OHCHR) and The Joint United Nations Programme on HIV/AIDS (UNAIDS) formulated the International Guidelines on HIV/AIDS and human rights (Guidelines). This was in line with the General Comment on health, which includes access to essential drugs like ARVs, and the resolution of the Commission on Human Rights. ${ }^{44}$ The guidelines built on expert advice to integrate the principles and standards of international human rights law into the HIV/AIDS response. They are non-binding but have been argued to form a 'soft law' bridge between 'hard law' international obligations and the practice of countries. ${ }^{45}$ The guidelines provide, inter alia, that:

Universal access to HIV/AIDS prevention, treatment, care and support is necessary to respect, protect and fulfill human rights related to health, including the right to enjoy the highest attainable standard of health. Universal access will be achieved progressively over time. ${ }^{46}$

Following the 2001 developments resulting from the United Nations Declaration of Commitment on HIV/AIDS and the Doha Declaration, in 2002, the OHCHR and the UNAIDS updated the Guidelines. The revision was also meant to take into account the obligation of countries to provide ARVs as part of the right to health as

40 See art. 15 of the Declaration.

41 Onyemelukwe, supra note 16, p. 458.

42 See A. E. Boyle, 'Some Reflections on the Relationship of Treaties and Soft Law', 48 International and Comparative Law Quarterly (1999): 902, where the author describes how soft instruments may become non-binding law.

43 D. Patterson and L. London, 'International Law, Human Rights and HIV/AIDS', 80 Bulletin of the World Health Organisation (2002): 964, 966.

44 UNAIDS and OHCHR, International Guidelines on HIV/AIDS and Human Rights (1997). See also UNAIDS and OHCHR, International Guidelines on HIV/AIDS: Revised Guideline 6 (2002). The guidelines were developed by the Second International Consultation on HIV/AIDS and Human Rights. The Guidelines were drawn up after the Secretary-General of the UN recommended to the Commission Human Rights that guidelines were needed to outline clearly the application of human rights in the context of HIV/AIDS.

45 Watchirs, supra note 18.

46 The guidelines were drawn up after the Secretary-General of the UN recommended to the Commission Human Rights that guidelines were needed to outline clearly the application of human rights in the context of HIV/AIDS. 
interpreted by the CESCR. ${ }^{47}$ This resulted in the Revised Guideline 6 (Revision) which specifically refers to HIV/AIDS treatment and recommends that enactment of legislation by countries to provide for HIV-related goods, safe, services and information so as to ensure, among other things, safe and effective medication. ${ }^{48}$ The Revision requires countries to ensure access to essential medications at affordable prices, and on a non-discriminatory, sustainable basis. ${ }^{49}$ It further requires countries to take measures to ensure for all persons, on a sustained and equal basis, the availability and accessibility of HIV-related goods, including anti-retroviral and other safe effective medicines. It calls upon countries to pay a particular attention to vulnerable individuals and populations. ${ }^{50}$ The Revision further recommends that countries increase their budgetary allocation in order to provide sustainable access to ARVs and other HIV/AIDS related goods. ${ }^{51}$ Despite the framing of the Guidelines which recognises that the right to health must be achieved progressively over time, it states that countries have an immediate obligation to take steps as quickly as possible to ensure, among other things, access to treatment. ${ }^{52}$

Closer to home, the African Charter on Human and Peoples' Rights (African Charter) provides for the right to health. ${ }^{53}$ This arguably includes the obligation to provide access to AIDS drugs. In terms of communications, however, there has been no access to AIDS drugs - related case submitted to the African Commission on Human and People's Rights (African Commission).$^{54}$ In the absence of any jurisprudence on the subject, there is no point of reference in terms of interpretation by the African Commission on state obligation to provide HIV/AIDS drugs. The African Commission however did find that states have an obligation to ensure that health care facilities and commodities including drugs are made available to citizens. ${ }^{55}$ There have however been illustrious domestic decisions on legal obligation to provide access to HIV/AIDS treatment, for example, in South Africa, the Constitutional Court handed down an instructive judgment in Minister of Health $v$ Treatment Action Campaign (popularly known as the TAC case). ${ }^{56}$ The Treatment Action Campaign (TAC), a ginger non Governmental Organisation, launched a constitutional challenge,

47 Supra note 12; UNAIDS and OHCHR, International Guidelines on HIV/AIDS and Human Rights (1997). See also UNAIDS and OHCHR, International Guidelines on HIV/AIDS: Revised Guideline 6 (2002).

48 Ibid.

49 Ibid

50 lbid.

51 Ibid, para (c).

52 Preface to Revised Guideline 6, supra note 47.

53 See art 16 of the African Charter. The African Charter, also known as the 'Banjul Charter', was adopted by the African Union in Nairobi, Kenya, in June 1981 and entered into force in October 1986.

54 See generally S. Gumedze, 'HIV/AIDS and Human Rights: The Role of the African Commission on Human and People's Rights', 4 African Human Rights Law Journal (2004): 181.

55 See Purohit and Moore V The Gambia Communication 241/2001 (2003) AHRLR 96 (ACHPR 2003). Decided at the $33^{\text {rd }}$ ordinary session of the African Commission (15-29 May 2003).

5620025 SA 721 CC. 
alleging a violation of the right to access health care services and demanding a program to make the drug available throughout the country. At the time of the case, South Africa was in the midst of an HIV/AIDS epidemic with more than 6 million people infected. The Court ordered the Government to extend availability of Nevirapine to hospitals and clinics, to provide counselors; and to take reasonable measures to extend the testing and counseling facilities throughout the public health sector.

More recently, the Protocol to the African Charter on Human and Peoples' Rights on the Rights of Women in Africa (African Women's Protocol) became the first document to provide for binding obligations on the right to health with specific mention of HIV/AIDS. ${ }^{57}$ The African Women's Protocol requires, inter alia, that state parties take all appropriate measures to provide adequate, affordable and accessible health services, including information, education and communication programmes to women especially those in rural areas. ${ }^{58}$ This obligation is particularly crucial in light of the fact that women form the larger population of people affected with HIV/AIDS.

In recent resolutions, the African Commission has recognised that access to medications in the context of a pandemic such as HIV/AIDS is a fundamental element to realising the right to health and calls upon countries to pursue policies which ensure the availability, accessibility and affordability of pharmaceutical products and medical technologies necessary for the treatment of HIV/AIDS. ${ }^{59}$ It further called upon countries to adopt and implement legislations and positive measures in accordance with international law and international agreements acceded to in order to safeguard access to pharmaceutical and medical technologies from any limitations by third parties. ${ }^{60}$

57 Adopted in Maputo in July 2003 and entered into force 25 November 2005, available at http://www.africa-union.org (accessed 10 March 2006).

58 Art. 14(2) (a). See also, R. Amollo 'A Critical Reflection on the African Women's Protocol as a means to Combat HIV/AIDS among Women in Africa', unpublished masters thesis, University of Pretoria. Available at https://www.up.ac.za/dspace/items-by author?author=Amollo\%2C+Rebecca 10k; R. Amollo, 'The Protocol on Women's Rights in Africa: What does it say about Gender-based violence and HIV/AIDS?', 2(1) Iminyango Quarterly Newsletter (2007), available at www.gbvhiv.org.za/iminyango-newsletters/iminyangovol2-no-1.pdf; F. Banda, 'Blazing a Trail: The African Women's Protocol comes into Force', 50 Journal of African Law (2006): 72; M. S. Nsibirwa, 'A Brief Analysis of the Draft Protocol to the African Charter on Human and Peoples' Rights', 1 African Human Rights Law Journal (2001): 40; R. Karugonjo-Segawa, 'The Protocol to the African Charter on Human and People's Rights on the Rights of Women in Africa' (2005) Research Partnership, Danish Research Institute for Human Rights; S.A. Kaniye-Ebeku, 'A New Hope for African Women: Overview of Africa's Protocol on Women's Rights', 13 Nordic Journal of African Studies (2004): 264, available at http://www.njas.helsinki.fi/pdf-files/vol13num3/ ebeku.pdf (accessed 12 April 2006).

59 See Commission on Human Rights, 'Access to Medication in the Context of Pandemics such as HIV/AIDS, Tuberculosis and Malaria', 56 ${ }^{\text {th }}$ Session of the Commission on Human Rights E/CN.4/2003/L.33. See also Commission on Human Rights, Resolution 2001/33, 'Access to Medication in the Context of Pandemics such as HIV/AIDS', adopted 20 April 2001 (E/CN 4 RES.2001.33) and art. 15 of the Declaration of Commitment on HIV/AIDS UNGA Res.A/ Res/S-26/2).

60 Art. 5. 
Still on the African continent, the African Union (AU), and its predecessor, the Organisation of African Unity (OAU) adopted a number of declarations pertaining to HIV and AIDS. One of the most significant of these is the 2001 Abuja Declaration on HIV/AIDS, Tuberculosis and Other Related Infectious Diseases (Abuja Declaration). ${ }^{61}$ In terms of access to ARV drugs and HIV/AIDS, African heads of state resolved, inter alia, to support the donor community funds providing ARV programmes in Africa. ${ }^{62}$ Further, African leaders undertook to mobilise all the human, material and financial resources required to provide care and support and quality treatment to their populations infected with HIV/AIDS, among other things, and to organise meetings to evaluate the status of implementation of the objective of access to care. ${ }^{63}$

Even more pertinent, the heads of state resolved under the Abuja Declaration to enact and utilise appropriate legislation and international trade regulations to ensure the availability of drugs at affordable prices and technologies for treatment, care and prevention of HIV/AIDS, amongst others. ${ }^{64}$ This was accompanied by the resolution to take immediate action to use tax exemption and other incentives to reduce the prices of drugs and all other inputs in health care services for accelerated improvement of the health of our populations. ${ }^{65}$ It can therefore be concluded that at Abuja, there was political consensus that access and availability of affordable drugs was pivotal to AIDS care efforts.

Also notable among the efforts on the African continent is the Solemn Declaration on Gender Equality in Africa in which the AU assembly called for an accelerated implementation of gender specific legal measures to combat $\mathrm{HIV}$ and AIDS. ${ }^{66}$ Within the context of the skewed incidence and prevalence of HIV/AIDS amongst women, this Declaration represents the need to accelerate efforts to make drugs available to vulnerable populations.

Flowing from the above international and regional right to health framework, it is inevitable to make the argument that at least, if a country can not afford the skills, technology and means to produce ARVs and other drugs, they should make

61 Adopted at the 24-7 April 2001 summit in Abuja, Nigeria.

62 See paragraph 29 of the Declaration.

63 Para 30.

64 Para 31.

65 Para 31.

66 At the Third Ordinary Session of the African Union (AU) Assembly of Heads of State and Government in Addis Ababa, Ethiopia, in July 2004, the Heads of State and Government adopted the Solemn Declaration on Gender Equality in Africa (SDGEA) See Para 1 of the SDGEA. It is also arguable that the position of the African Union can be seen through its resolutions in sessions of the AU and through its other organisations like NEPAD. NEPAD has, however, been criticised for not embodying issues related to gender and HIV/AIDS. The NEPAD document is available at http://www.nepad.org/AA0010101.pdf (accessed 12 July 2006). The NEPAD website http://www.nepad.org also contains other NEPAD texts such as the communiqués, legal instruments and reports. For a critique on human rights in NEPAD, see generally, E. Baimu, 'Human Rights in NEPAD and its Implications for the African Human Rights System', 2 African Human Rights Law Journal, (2002): 301; S. Hlupekile Longwe, 'Assessment of Gender Orientation of NEPAD', available at http://dawn.thot.net/nepad1.html (accessed 12 March 2008). 
effort to procure a means of making available the medicines to its citizens. ${ }^{67}$ In recent times, within this argument, there has been the concomitant debate over patent law in relation to the Agreement on Trade-Related Aspects of Intellectual Property Rights (the TRIPS Agreement, 1994) of the WTO. ${ }^{68}$ This regime will be discussed in detail shortly in this paper. This debate has inevitably extended to the best means to enable poor countries without sufficient manufacturing capacity to make effective use of compulsory licensing provisions in order to gain access to essential medicines. ${ }^{69}$ In this midst, some developing countries have recently modified their patent laws to conform to the TRIPS standards, given the 2016 deadline for developing countries. ${ }^{70}$ Safeguards to protect public health have been incorporated into the TRIPS Agreement but practically speaking, most governments in the sub Saharan African continent have been reluctant to exercise such rights for fear of international trade and political ramifications, particularly in the area of trade sanctions..$^{71}$ A report ${ }^{72}$ shows that governments of developing countries are not willing to be named as seeking to import generic versions of patented drugs. This has been attributed to fear of censure. For example, Brazil and Thailand were heavily criticised by the pharmaceutical industry as well as by some governments when they used other flexibilities in TRIPS rules to suspend patents on drugs for domestic public health programmes. ${ }^{73}$

\section{UNDERSTANDING PATENTS, THE TRIPS AGREEMENT, DOHA DECLARATION, THE AUGUST 30 DECISION AND HONG KONG AMENDMENT}

On the strength of the above discussion, there is no doubt that HIV/AIDS and access to ARVs is a critical human rights issue. This ushers in the need for pharmaceutical industries to cooperate in order to make drugs available and accessible. The fields of intellectual property and human rights have however never been comfortable bedfellows. On the face of it, they could even work at cross purposes. It is this relationship between strangers that has come to occupy the debate between intellectual property regime and access to medicines. The two subjects developed in virtual isolation from each other although in recent years, international standard setting activities began to map their previously unchartered

67 See, generally, Mushayavanhu, supra note 10.

68 D. Gervais The TRIPS Agreement: Drafting History and Analysis, $2^{\text {nd }}$ edn, Sweet and Maxwell (2003).

69 R. Mayne, 'The Global Campaign on Patents and Access to Medicines: An Oxfam Perspective', in P. Drahos and R. Mayne (eds), Global Intellectual Property Rights: Knowledge, Access, and Development, Palgrave Macmillan (2003), pp. 244-58.

70 See para 7 of the Doha Declaration.

71 Cohen, supra note 7,1 .

72 International Centre for Sustainable Trade and Development, 'Rwanda Becomes First Country To Try to use WTO Procedure to Import Patented Hiv/Aids Drugs', in Bridges Weekly Trade News Digest, 11:27 (25 July 2007), available at http://ictsd.net/i/news/bridgesweekly/7614/.

73 H. P. Hestermeyer, 'Canadian-made Drugs for Rwanda: The First Application of the WTO Waiver on Patents and Medicines', International Economic Law Edition, 11: 28 (10 December 2007), available at http://www.asil.org/insights/2007/12/insights071210.html. 
intersections. ${ }^{74}$ This relationship has been fought over with one view propounding that human rights and intellectual property are fundamentally in conflict, ${ }^{75}$ and the other arguing that both areas are concerned with the same fundamental question of defining the appropriate scope of private monopoly power that gives authors and inventors a sufficient incentive to create and innovate, while ensuring that the consuming public has adequate access to the fruits of their efforts. ${ }^{76}$ Indeed, this divide has continued to characterise the trajectory of the two discourses as evidenced in the TRIPS Agreement and its subsequent modifications. This tension has also been expressed in the attempts so far to make use of the WTO system by member countries. These will be discussed shortly.

Globally, recent developments seem to show that cheaper drugs are being made available in developing countries due to a series of international initiatives and support from developed countries such as the Global Fund, the United States (US) government's President Emergency Plan Fund for AIDS Relief (PEPFAR) and the Clinton Foundation which has been able to strike some deals with pharmaceutical companies to sell HIV/AIDS drugs at a cheaper price in some developing countries. ${ }^{77}$ It however remains to be seen whether developing countries can do more, especially as balanced against trade and commercial interests. It is within this context that the UN reported:

Globally, trade policy provisions need to be used more effectively to increase access to care. The availability of low-cost generic drugs needs to be expanded, in accordance with national laws and international trade agreements and with a guarantee of their quality ...We need to find ways of more effectively using trade policy provisions, such as compulsory licensing or parallel importation, to increase access to care. The availability of low cost generic drugs needs to be expanded, in accordance with national laws and international trade agreements and with guarantees of their quality. ${ }^{78}$

\section{A. TRIPS and patents}

Simply put, patents are national rights, usually granted by the national patent office, with effects only in the area for which they have been granted. ${ }^{79}$ Patents

74 L. R. Helfer 'Human Rights and Intellectual Property: Conflict or Coexistence?', available at http://mipr.umn.edu.

75 See Intellectual Property Rights and Human Rights, Res. 2000/7, UN Sub-Comm'n on the Promotion and Protection of Human Rights, 52 ${ }^{\text {nd }}$ Sess. Pmbl. U.N. Doc. E/CN.4/Sub.2/RES/2007.

76 Helfer, supra note 74.

77 E. Durojaye 'Compulsory Licensing and Access to Medicines in post Doha Era: What hope for Africa?' 55 Netherlands International Law Review (2008): 33-72; 35; L. Altman, 'Clinton Group Gets Discount for AIDS Drugs', New York Times, 24 October 2003, p. 1, where it was reported that the Foundation has struck a deal with some pharmaceutical companies to sell ARVs at cheaper prices in some countries in Africa and the Caribbean.

78 Report of the UN Secretary General to the UN General Assembly meeting issued on 16 February 2001, UN Doc.A/55/779.

79 Hestermeyer, supra note 73. 
and intellectual property rights (IPRs) are, in general, used to give a certain exclusionary right that can not otherwise be given to the owner of intangible property on a competitive market. ${ }^{80}$ The inventor or owner is given this right since the nature of the property otherwise allows it to be used by several manufacturers at the same time, as the property is not individually appropriable. One of the defences for this argument is the moral right an inventor has to use his own invention. ${ }^{81}$

The modern protection of intellectual property rights developed first as national legislation in developed countries, followed by international agreements such as the Paris Convention, ${ }^{82}$ the Berne Convention ${ }^{83}$ and other co-operations, eventually leading to the Agreement on Trade Related Aspects of Intellectual Property (TRIPS Agreement) ${ }^{84}$ It is important to note that the Paris Convention excludes patenting of pharmaceutical products. The TRIPS Agreement is an integral part of the World Trade Organisation agreements. It is considered the most significant development in intellectual property in recent years alongside the creation of the World Intellectual Property Organisation (WIPO) at the Stockholm Conference. ${ }^{85}$ Its regime prescribes a minimum level of patent protection that WTO members must provide. It also provides for the members to grant patents and the procedure to be followed. ${ }^{86}$ A patent on a product allows the patent-holder to prevent third parties from 'making, using, offering for sale, selling or importing' the product in the territory of the grant without its consent. ${ }^{87}$ To secure protection of an invention in several countries, inventors must file for patents in all of them. Pharmaceutical companies generally patent their inventions in all major markets.

The TRIPS Agreement also gave members some time to adapt their national laws to the new standards.$^{88}$ Currently, only members of least-developed countries (LDCs) remain exempt from the obligation to grant pharmaceutical patents. ${ }^{89}$ Patents generally allow inventors to sell their product at higher prices, creating an incentive to invest in research and development. This became a threat for access to medicines for poor countries. ${ }^{90}$ The issue was recognised by the WTO in its 2001

80 P. Torremans, Holyoak and Torremans Intellectual Property Law, $3^{\text {rd }}$ edn (2001) at 13 (P Torremans, Intellectual Property Law).

81 S. Picciotto, 'Defending the Public Interest in TRIPS and the WTO', in P. Drahos and R. Mayne (eds), Global Intellectual Property Rights - Knowledge, Access and Development (2002), pp. 224-43; 225.

82 Paris Convention for the Protection of Industrial Property 1883.

83 Berne Convention for the Protection of Industrial Property 1886.

84 See TRIPS Agreement, supra note 9.

85 Gervais, supra note 68.

86 Arts 27.1, 29, 33 of the TRIPS Agreement.

87 Art. 28.1 (a) TRIPS Agreement.

88 Art. 65.4 TRIPS Agreement.

89 Until 1 January 2016: Extension of the Transition Period under Article 66.1 of the TRIPS Agreement for Least-Developed Country Members for Certain Obligations with Respect to Pharmaceutical Products, Doc. IP/C/25 (1 July 2002); Least-Developed Country Members Obligations under Article 70.9 of the TRIPS Agreement with Respect to Pharmaceutical Products, Doc. WT/L/478 (12 July 2002).

90 Hestermeyer, supra note 73. 
Doha Declaration on the TRIPS agreement and public health. ${ }^{91}$ This tension will be discussed in the next section of this paper.

The TRIPS Agreement also allows for a grant of a compulsory license. This is a license granted by the government allowing the use of the invention without the patent holder's authorisation. ${ }^{92}$ The grant of compulsory licenses must be predominantly for the supply of the domestic market. ${ }^{93}$ The latter requirement may be waived, for example, in times of national emergency. The waiver only applies in the case of licenses granted to remedy anti-competitive practices. This provision creates a problem for countries with insufficient manufacturing capacities for drugs. Until recently, this usually meant importing the drug from India, which did not grant product patent protection for drugs and is home to quality-assured drugs produced in large volumes and affordable prices. ${ }^{94}$ India's ability to manufacture the newest generation of drugs is now restricted as all developing countries have to grant patent protection for new patentable drugs. A generic manufacturer thus needs a compulsory license in its home country to produce and export a new, patented drug. Such a 'compulsory license for export' is not permissible. ${ }^{95}$

Until recently, the above exception had been considered by the WTO to be sufficiently flexible to allow members to use a patented invention for the purposes of promoting the public interest in matters of vital importance, such as the protection of public health. However, in recent years, critics of TRIPS have observed that while the flexibility to authorise non-consensual use of a patent is of potential benefit to developed countries with domestic manufacturing capacity in a particular field of technology, it is of limited benefit to countries with insufficient or no such capacity. This is particularly problematic in the pharmaceutical field as it prevents such countries from using TRIPS to address their often very substantial public health problems. This problem is compounded by the fact that TRIPS also requires that any non-consensual use of a patented invention be predominantly for the supply of the domestic market of the country granting the authorisation. This puts an obvious limit on the ability of countries with manufacturing capacity in the pharmaceutical sector to authorize the manufacture of patented pharmaceutical products for export to countries unable to manufacture their own.

Accompanying the above rigid provisions is the fact that the TRIPS Agreement compared to earlier intellectual property agreements is subject to the WTO dispute settlement mechanism. ${ }^{96}$ Non-compliance with the treaty can be challenged through this hard-edged system, in which rulings by the WTO panels and Appellate Body are backed by the threat of trade sanctions. ${ }^{97}$ It is therefore little wonder

91 Doha Ministerial Declaration on the TRIPS Agreement and Public Health, Doc. WT/MIN(01)/DEC/2 20 November 2001.

92 See art. 31 of the Agreement.

93 Art. 31 (f).

94 K. M. Bombach, 'Can South Africa fight AIDS? Reconciling the South Africa's Medicines and Related Substances Act with the TRIPS Agreement', 19 Boston University International Law Journal (2001): 289.

95 See art. 31(f) of the Agreement.

96 See Part V of the Agreement.

97 See Part V of the Agreement. 
that some scholars have described the agreement as having teeth..$^{98}$ This provision, as was later shown, became a deterrent to most developing countries' ability to invoke compulsory licences. ${ }^{99}$ All the above issues led to the conclusion that the TRIPS Agreement was a major tactical victory for rich countries and pharmaceutical companies. ${ }^{100}$ Its one-size-fits all approach has been widely criticised for ignoring the obvious differences in capacities of countries. ${ }^{101}$ The above stringent rigours of the TRIPS were soon to provoke global concern. Apprehension about the impact of the TRIPS Agreement began to grow in the late 1990s following the passing of South African Medicines and Related Substances Control Amendments Act and the subsequent litigation by 39 multinational pharmaceutical companies aimed at blocking implementation of certain of its features. ${ }^{102}$ The litigation was viewed as a misuse of the TRIPS to advance the originator industry's grievances with generic substitution requirements, price controls, and parallel importation. This litigation, alongside the conduct of the United States and European Union trade authorities in pressuring South Africa to refrain from taking steps that would interfere with the industry's pricing practices and market advantage, became an eye opener to the concerns about the impact of intellectual property rules on access to medicines particularly in the developing world. ${ }^{103}$ This concern is made worse by the pandemic levels of HIV/AIDS in sub Saharan Africa.

\section{B. Doha Declaration}

A general dissatisfaction amongst mainly less developed countries in sub-Saharan Africa led to a challenge of the scope, interpretation and the application of the TRIPS Agreement flexibilities. This led to the adoption of the Doha Declaration on the TRIPS Agreement and Public health (Doha Declaration) in 2001. ${ }^{104}$ The Doha set the stage for the reconsideration of many aspects of the TRIPS including, the compulsory licensing provisions in order to accommodate those countries that lack manufacturing capacity, ${ }^{105}$ pricing of medicine, ${ }^{106}$ access to

98 J. H. Reichman, 'The TRIPS Agreement Comes of Age: Conflict or Cooperation with the Developing Countries?', 32 Case Western Reserve Journal of International Law (2000): 441.

99 India, South Africa and Brazil opposed wealthy countries bringing shame as it was seen as greed on the part of the North and its industry was killing millions of people in the South.

100 See M. A. Santoro, 'Human Rights and Human Needs: Diverse Moral Principles Justifying Third World Access to Affordable HIV/AIDS Drugs', 31 North Carolina Journal of International Law and Commercial Regulation (2006): 923, 926.

101 Mushayavanhu, supra note 10,145.

102 Pharmaceutical Society of South Africa and others: New Clicks South Africa (Pty) Limited v Minister of Health and another: Tshabalala-Msimang NO and Another 542/04, 543/04.

103 Meeting Report: Access to Medicines and Intellectual Property: An International Expert Meeting on Canada's Access to Medicines Regime, Global Developments, and New Strategies for Improving Access, 19-21 April, 2007, Ottawa, Canada.

104 WTO Ministerial Declaration on the TRIPS Agreement and public health, WTO/MIN (01)/DEC/2, adopted on 14 November 2001.

105 Para 6.

106 Para 3. 
medicines, ${ }^{107}$ and reiterated the right of WTO members to determine what constitutes a national emergency or other circumstances of extreme emergency. Even more, the Doha Declaration gives least developed countries until 2016 to provide for patent protection for their pharmaceutical products. ${ }^{108}$ In addition, developed countries are under the obligation to assist developing countries in technology and skills transfer. ${ }^{109}$ The Doha Declaration further reaffirms member states commitment to flexibilities under the TRIPS, for example, compulsory licensing. ${ }^{110}$ The use of compulsory licensing should promote access to generic medicines through local production by allowing a government agency or a private company to manufacture pharmaceutical products in the public interest without the patent holder's consent. ${ }^{111}$ Compulsory licensing is a policy tool that can be adopted to address situations where the price of drugs is beyond the reach of poor people, or where there is a need to promote technology transfer and establish a technological base, especially by countries that have insufficient or inadequate manufacturing capacity. The Declaration also recognises the gravity of the public health problems affecting many developing and least developed countries, especially those resulting from HIV/AIDS, among others. ${ }^{112}$ It can therefore be safely said that the Doha Declaration came after TRIPS as an assurance that human rights principles would inform the interpretation of the TRIPS Agreement.

Compulsory licensing, interpreted within the parlance of the Doha Declaration, should go a good way in alleviating the issue of inaccessibility to ARV drugs and other drugs. However, most countries on the subcontinent have obsolete patent laws modeled along colonial lines. These laws do not comply with or make use of possibilities under TRIPS. This is not helped by the insufficient manufacturing capacities of most developing countries. Hence, with regard to making use of the TRIPS flexibilities, one of the important aspects of the Doha Declaration is Paragraph 6 which obligated the Council for TRIPS to find an expeditious solution to the problem of WTO member countries with insufficient or no manufacturing capacities in the pharmaceutical sector. This has led to the WTO General Council Decision which is discussed next.

\section{WTO General Council Decision 2003}

The WTO General Council Decision of August 302003 on the implementation of Paragraph 6 of the Doha Declaration on the TRIPS Agreement and Public Health (briefly known as the 30 August Decision/Waiver Decision) allows member

107 WTO: 2001.

108 Para 7 of the Declaration.

109 Para 7 of the Declaration.

110 Para 5. Other flexibilities under the TRIPS include parallel importation and the provisions for early working (also known as the Bolar provision).

111 It also promotes competition policies to remedy anti-competitive practices and patent abuse, thereby lowering the prices of medicines; See, generally, S. K. Sell, 'Trade Issues and HIV/AIDS', 20 Wisconsin International Law Journal (2001-2): 481, 513.

112 Para 1 of the Declaration. 
countries to authorise someone other than the patent holder to manufacture a lower cost version of a patented drug or medical device for export to developing countries that do not have the capacity to manufacture such products. The decision was meant to facilitate access to medicines in developing countries and was the outcome of intense and detailed two year multilateral negotiations. ${ }^{113}$ By that decision, WTO members agreed to waive certain obligations in the TRIPS Agreement which were thought to be a potential barrier to effective responses to health emergencies. ${ }^{114}$ The main provision of the decision waives the obligations of WTO members under Article 31(f) of the TRIPS Agreement for compulsory licenses to produce and export pharmaceutical products to eligible importing members for public health problems. ${ }^{115}$ In effect, the decision allows members with pharmaceutical manufacturing capability to amend their patent laws to permit the non-consensual use of patented inventions to manufacture and export the pharmaceutical products required by other members to respond to their public health problems, especially those resulting from HIV/AIDS, malaria, tuberculosis, and other epidemics. Thus, the waiver was meant to make it easier for poorer countries to obtain cheaper generic versions of patented medicines by setting aside a provision of the TRIPS Agreement that could hinder exports of pharmaceuticals manufactured under compulsory licences to countries that are unable to produce them.

\section{The Hong Kong Amendment}

On 6 December 2005, WTO members approved changes to the intellectual property agreement making permanent the 30 August Decision. ${ }^{116}$ The decision directly transforms the 30 August 2003 'waiver' into a permanent amendment of

113 Decision of 30 August 2003 on the Implementation of Paragraph 6 of the Doha Declarationon the TRIPS Agreement and Public Health, Doc. IP/N/10/CAN/1 (8 October 2007).

114 Minutes of Meeting. Held in the Centre William Rappard on 25, 26 and 30 August 2003, Doc. WT/GC/M/82 (13 November 2003) paras 29 et seq. Implementation of Paragraph 6 of the Doha Declaration on the TRIPS Agreement and Public Health, Doc. WT/L/540 (2 September 2003). The Decision is a waiver under art. IX WTO Agreement, even though its content at times oversteps the content of a waiver and comes close to an amendment of the TRIPS Agreement.

115 To put the mechanism into operation, the importing member must notify the WTO's Council for TRIPS of the name and expected quantity of the product, confirm that it has established that it has insufficient or no manufacturing capacity for the product in question (unless it is an LDC), and confirm that it has granted or intends to grant a compulsory license if the product is patented in its territory. The exporting member can then issue a compulsory license limited to the quantity of the drug necessary for the notifying importing member with the whole production going to that member. It must require the beneficiary to identify the drugs to prevent re-imports, e.g. by adding a special color, and to post quantities and distinguishing features of the drug on a website before shipment begins. Several importing members can pool as importers. The exporting member has to notify the Council for TRIPS of the grant of the license and its conditions. The notifications by importing and exporting Members do not need approval by the WTO. The mechanism is subject to an annual review by the Council for TRIPS. As compulsory licenses for export are granted under national law, exporting members are required to amend their patent laws for the mechanism to work. Several members have done so, albeit not in a uniform manner.

116 WTO press release, 'Members OK Amendment to make Health Flexibility Permanent' (6 December 2005), available at http://www.wto.org/english/news_e/pres05_e/pr426_e.htm. 
the WTO Agreement on Trade-Related Aspects of Intellectual Property Rights (TRIPS). The amendment is designed to match the 2003 waiver as closely as possible. As of March 2008, only 13 countries have supported the Hong Kong Amendment. ${ }^{117}$ It is important to bear in mind that Rwanda, on behalf of the Africa Group, has been critical of the Hong Kong Amendment. ${ }^{118}$

\section{MANOEUVRING THE WTO DECISION TERRAIN: CANADA ADOPTS THE JEAN CHRÉTIEN PLEDGE TO AFRICA ACT, RWANDA NOTIFIES THE WTO}

A negligible number of developed countries and regional groups have established domestic regimes to implement the WTO General Council Decision 2003. In North America, Canada established the Jean Chrétien Pledge to Africa Act 2004. The European Union has issued a directive regulating the export of generic pharmaceutical drugs. ${ }^{119}$ The Netherlands, Switzerland and Norway have also established national regimes. In Asia, India, China and South Korea have all developed legislative measures to allow for the export of pharmaceutical drugs in order to address public health concerns. It is also important to note that while these countries have been making effort to be in tune with the WTO Decision, others have remained outrageously resistant to the move, notably, the United States of America, Japan and Australia. ${ }^{120}$ Globally, some of the ginger groups that have pushed the access to medicine agenda include India, Brazil, South Africa, Thailand and China. This has come with repercussions as demonstrated in the case of Thailand. In 2006 and 2007, Thailand received a critical notice from the United States Trade Representative in its Special 301 Report, and the threat of a boycott of products from Abbott Laboratories, as well as widespread outrage from members of the brand-name pharmaceutical industry when she issued compulsory licences in respect of, inter alia, ARVs. ${ }^{121}$

As previously indicated, states can engage in procurement of ARVs as a means to make available AIDS drugs. This is particularly important for most sub Saharan African countries, which are not endowed with the means to produce medicines locally. The positive duty to fulfill and promote availability of AIDS drugs would therefore involve efforts like negotiating with other governments or public and private entities producing drugs. Taking benefit of the TRIPS regime comes along with the obligation to be TRIPS compliant, by, for example, passing patent laws in line with the regime. On the African continent, research shows that at the time of the entry into force of the TRIPS Agreement, Angola and Malawi were among the

117 Including the United States, Switzerland, El Salvador, South Korea, Norway, India, Philippines, Israel, Japan, Australia, Singapore, China and the European Union.

118 S. Shashikant, 'Heated Discussions as TRIPS and Health Deadline is Missed' (6 April 2005). South Development Monitor SUNS 5772, Geneva, available at http://www.cptech.org/ ip/wto/suns04042005.html.

119 Rimmer, supra note 2, p. 90.

120 The United States administration of George W. Bush has instead pursued a course of bilateral and regional free trade agreements to raise the levels of patent protection of pharmaceutical drugs in a range of jurisdictions.

121 Government of Canada (2007: 32-3). 
countries in sub Saharan Africa that excluded the patentability of pharmaceutical products. ${ }^{122}$ There have however been some recent developments although patent law generally remains obsolete in the sub continent. ${ }^{123}$

The first country to implement the WTO August 30 Decision was Canada. ${ }^{124}$ She entered into the Agreement Establishing the World Trade Organisation in 1994. It was therefore part of the process leading to both the Doha Declaration and the August 30 Decision. In light of these developments, in September 2003, Stephen Lewis challenged the Government of Canada to amend its patent law to give poor countries devastated by AIDS a cheap source for drugs. ${ }^{125}$ He made a plea to Canada as a major industrial country, and one of the G7 countries to announce the manufacture and export of generic drugs to Africa. ${ }^{126} \mathrm{He}$ concluded that 'If a major Western government would undertake the simple legislative amendment allowing for the production and export of generic anti-retrovirals, it would make a tremendous difference for Africa'. ${ }^{127}$ This was also amidst campaigns in the country by other ginger groups like Médecins Sans Frontiéres and the Canadian HIV/AIDS Legal Network. Less than 2 months later, Canada announced the introduction of a new Bill to provide for low cost drugs to fight AIDS in developing countries. The proposed law was dubbed - An Act to amend the Patent Act and the Food and Drugs Act - the Jean Chrétien Pledge to Africa Act 2004 (Canada). ${ }^{128}$ The Jean Chrétien Pledge to Africa Act provides for compulsory licences to authorise the manufacture and export of an eligible drug or medical device to an eligible country.

\section{A. Canada enacts a Medicines Regime}

In May 2004, in a bid to implement the August 30 Decision, Canada adopted a detailed legislative framework referred to as 'Canada's Access to Medicines Regime' (CAMR or Regime). ${ }^{129}$ It has become a classic example, demonstrating how developed countries can use their mechanisms to benefit Low and Middle Income Countries (LMICs). With the implementation of the Use of Patented Products for International Humanitarian Purposes Regulations, Canada became

122 WIPO 2000: 36.

123 For patent law developments on some African countries, see, generally, Mushayavanhu, supra note 10.

124 Canada had been at the forefront of the WTO processes.

125 Rimmer, supra note 119, p. 91.

126 S. Lewis (2003) 'The Politics of Resource Allocation. Statement by United Nation Secretary General's Special Envoy on HIV/AIDS', Nairobi, Kenya, available at http://www.awcfs.org/ Icasa/DayFive/StephenLewis4.html (accessed 30 July 2008).

127 S. Nolen, 'Spearhead AIDS Fight, UN Envoy Tells Canada'. Globe and Mail, 25 September 2003 A,1. See also Rimmer, supra note 114, p. 91.

128 SC 2004, c 23. Available at www.canlii.org/ca/as/2004/c23. Jean Chrétien was enthusiastic in this area. The name was in his honour.

129 On 14 May 2004, the Jean Chrétien Pledge to Africa Act (formerly Bill C-9) received Royal Assent. This legislation amended the Patent Act and the Food and Drugs Act to provide the framework enabling Canada to respond to a decision of 30 August 2003 of the General Council of the World Trade Organisation (WTO). 
one of the first countries to permit the grant of authorisations to Canadian pharmaceutical manufacturers who wish to supply countries having inadequate or no pharmaceutical manufacturing capabilities with lower-cost versions of patented pharmaceutical products. This law enables Canada to export generic medicines to eligible countries that cannot produce them.

What is further important to note about this law is that it departed from the WTO's position. The August 30 Decision is between member countries of the WTO and does not apply to countries not party to the organisation. Nevertheless, Canada chose to implement the decision in a manner that enables both developing and least developed non-WTO member countries to participate as importers of eligible patented pharmaceutical products. ${ }^{130}$ The amendment came into force in May 2005. ${ }^{131}$ It imposes a number of conditions for obtaining a compulsory license for export, including the conditions of the 2003 WTO decision but also additional ones.

The law has been described as less permissive than some of the other national regimes. ${ }^{132}$ A review of its scheme noted: ${ }^{133}$

Canada's Access to Medicines Regime contains a number of measures that have not been emulated elsewhere. These include its reliance on pre approved lists of products eligible for export and countries eligible to import them and making the grant of an export licence contingent upon the health and safety review of the product by the exporting authority. In addition, whereas many other regimes waive the requirement that a pharmaceutical manufacturer request a voluntary licence, in cases of a national emergency or circumstances of extreme urgency, Canada's Access to Medicines Regime does not.

The CAMR is meant to allow generic drug companies in Canada to produce and export lower-cost versions of brand-name drugs to developing countries. It provides a way for the world's developing and least-developed countries

130 A WTO member country must notify the WTO, which will post a notice on a dedicated WTO website. That notice must identify the name and the quantity of the required product and, if the product is protected by a domestic patent, indicate the member's intention to grant authorisation to use the invention pertaining to the product in question. Unless the importing member is a least developed country, the notice must also contain a declaration by that member that it has no or insufficient capacity to manufacture the required product. On the other hand, consideration by Canada for any non-WTO country seeking to import pharmaceutical products under the regime requires written notice to the government of Canada through diplomatic channels and is conditional upon agreement to specific criteria. Least developed country (LDC): government would be required to formally state that it will not import licensed products for commercial purposes, and that it will adopt measures consistent with the August 30th decision to prevent re-exportation of pharmaceutical products to other countries. Developing country: in addition to the above LDC requirements, the country must also qualify for official development assistance according to the Organisation for Economic Co-operation and Development (OECD). The country must also formally state that it is experiencing substantially the same conditions under which developing country WTO members on Schedule 4 may import licensed pharmaceutical products (e.g. urgent circumstances and insufficient manufacturing capacity).

$131 \$ 21.04(3)$ (c) Patent Act.

132 Rimmer, supra note 2, p. 92.

133 Government of Canada (2008), available at http://www.camr-rcam.gc.ca/index/_e.html. 
to import high-quality drugs and medical devices at a lower cost to treat the diseases that bring suffering to their citizens. It is one part of the Government of Canada's broader strategy to assist countries in their struggle against HIV/AIDS, tuberculosis, malaria and other diseases. ${ }^{134}$ Canada's Access to Medicines Regime provides a framework within which eligible countries can import less expensive generic versions of patented drugs and medical devices. All products exported under the Regime must meet the same rigorous requirements for safety, effectiveness and quality as those authorised for the Canadian market. The law therefore seeks to reconcile both commercial and humanitarian goals. ${ }^{135}$

To use the Regime, eligible countries must make an arrangement with pharmaceutical companies based in Canada. Non-governmental organisations can help countries to obtain and distribute drugs and medical devices through the Regime and can also obtain and distribute generic drugs on their own. Eligible countries may be able to obtain funding to support their purchase of medicines, although not directly through CAMR. The legislation upon which the Regime is based lists the pharmaceutical products eligible for export. These include drugs to treat HIV/AIDS, malaria, tuberculosis and other diseases. There are also measures in place for adding to the list of eligible products.

The road towards the first application of the mechanism was tussled by MSF, an international humanitarian organisation, and Apotex, a giant Canadian generic drug manufacturer, headquartered in Toronto. MSF committed itself to test the new law as a would-be purchaser of a generic product from Apotex. Apotex has been interested in the supply of generic drugs. ${ }^{136}$ At MSF's request, Apotex, which had been interested in the supply of generic pharmaceutical drugs for a mixture of philanthropic and commercial reasons, developed TriAvir, a single, fixed-dose combination drug that helps treat people living with HIV/AIDS. ${ }^{137}$ Apo-Triavir combines three patented brand-name drugs: zidovudine, lamivudine and nevirapine. This was developed with the view of potentially exporting it under a compulsory license to one or more developing countries. The national drug regulatory authority, confirmed that the product met the necessary standards required by Canadian law, a precondition of export. The product was subsequently approved by the 'Prequalification Programme' of the World health Organisation (WHO), thus providing some certainty to potential purchasers that the product and the manufacturer meet accepted standards. ${ }^{138}$ This process took several years.

134 Ibid.

135 The CAMR complements other humanitarian efforts by the government of Canada to assist leastdeveloped and developing countries in responding to public health problems.

136 The company is a veteran of patent litigation with brand-name pharmaceutical companies. It has been involved in numerous law suits in the Canadian courts, notably the Supreme Court of Canada decision in Apotex Inc. v. Wellcome Foundation Ltd. 2002 SCC (CanLII).

137 Apotex (2003). Apotex has been involved in numerous law suits in the Canadian courts - most notably, the Supreme Court of Canada decision in Apotex Inc. v. Wellcome Foundation Ltd. 2002 SCC 77 (CanLII).

138 For more information about the WHO Prequalification Programme, see http://mednet3.who. int/prequel. 


\section{B. Rwanda navigates the waters of Canada's Medicines Regime}

In the midst of the above quagmire, in a pioneer move, Rwanda notified the WTO of its intention to import ARV drugs from Canada. ${ }^{139}$ This was the first test of the waters of the WTO August 30 Decision and the CAMR. ${ }^{140}$ This was four years after the Decision. A country with a population of about 9.4 million people, Rwanda is one of the countries which collectively represent approximately 50 per cent of HIV infections worldwide. ${ }^{141}$ Rwanda has national mechanisms in place like the Rwanda National HIV/AIDS Strategic Plan (2006-2009), the HIV/AIDS Treatment and Care Plan (2003-2007), the National Prevention Plan and has established a Ministry in charge of HIV/AIDS and Other Epidemics in Rwanda. ${ }^{142}$ Currently, Rwanda faces a generalised epidemic, with an HIV prevalence rate of 3.1 per cent among adults aged 15 to 49 . The prevalence rate has remained relatively stable, with an overall decline since the late 1990s, partly due to improved HIV surveillance methodology. ${ }^{143}$ In general, HIV prevalence is higher in urban areas than in rural areas, and women are at higher risk of HIV infection than men. Young women aged 15 to 24 are twice as likely to be infected with HIV as young men in the same age group. ${ }^{144}$ Populations at higher risk of HIV infection include sex workers and men attending clinics for sexually transmitted infections. ${ }^{145}$

Rwanda is among the world's least developed countries, ranking 158 of 177 in the United Nations Development Program's 2006 Human Development Index. ${ }^{146}$ Some 60 per cent of the population lives in poverty. During the genocide in 1994, mass rape, sexual torture and psychological trauma were rife. Massive population flow following the genocide has resulted in an increase in the urban population. The country also faces a shortage of human resources throughout the health sector. Some of the Rwandans killed or displaced during the genocide, included a disproportionate number of highly skilled doctors, nurses and other health workers. ${ }^{147}$ Many health centers lack essential physical facilities, equipment and supplies. ${ }^{148}$ The country's state of health is therefore suffering.

In order for a country to fully benefit from the TRIPS Agreement, it has to put in place legislation to benefit from a better and negotiated status for least

139 See notification (IP/N/9/RWA/1), filed on 19 July 2007.

140 Kaiser Daily HIV and Aids Report, 'WTO Receives Notification From Canada Authorizing Generic Drug Company To Produce Combination Antiretroviral for Rwanda', 09 October 2007. Available at http://www.kaisernetwork.org/daily_reports/rep_index.cfm?hint=1\&DR_ID= 48039.

141 UNAIDS, Report on the Global AIDS Epidemic (2008).

142 WHO, Summary Country Profile on HIV/AIDS Treatment Scale-up - Rwanda (2008).

143 UNAIDS, supra note 3.

144 Ibid.

145 WHO, Summary Country Profile on HIV/AIDS Treatment Scale-up - Rwanda (2008).

146 United Nations Development Programme, Human Development Report (2006).

147 WHO, supra note 140.

148 Electricity supply is erratic throughout Rwanda, impacting hospitals, health centres and laboratories. Blood safety, data management and drug storage are all impacted by the erratic electricity supply. 
developed countries and flexibilities. Rwanda is a party to the World Intellectual Property Organisation (WIPO) Convention, the constituent instrument of the organisation since $1984 .{ }^{149}$ Rwanda has an observer status with the African Regional Intellectual Property Organisation (ARIPO) and is, hence, no party to different treaties and conventions regulated by the Organisation. ${ }^{150}$ Like most sub Saharan African countries, Rwanda applies a dualist approach to international law. The Constitution of the Republic of Rwanda states that:

Peace treaties and treaties or agreements relating to trade and international organisations and those which commit state finances, modify provisions of laws already adopted by Parliament or relate to the status of individuals, can only be ratified after authorisation by Parliament. ${ }^{151}$

In effect, in order for the TRIPS Agreement to take legal effect in Rwanda, the country will have to domesticate it through a national legislation. Rwanda has adhered to the TRIPS Agreement but has not complied with most of the requirements so far. The main law regarding pharmaceutical production in Rwanda is the Law on Pharmaceutical Art. ${ }^{152}$ Rwanda does not have a drug authority. ${ }^{153}$ Patents are recognised in Rwanda by a law on patents ${ }^{154}$ enacted in 1963 and a ministerial decree putting in application the law on patents. ${ }^{155}$ Under this law, the Minister of Commerce, Industry, Investment Promotion, Tourism and Cooperatives determines the conditions to be followed by whoever seeks a patent registration and protection for his invention. There are three types of patents in Rwanda: invention patents, import patents and improvement patents, all of which have a lifespan of 20 years. Whoever seeks any sort of patent makes an application to the Minister of Commerce, Industry, Investment Promotion, Tourism and Cooperatives. The application is accompanied by a full description of the invention, the drawings, patters or samples necessary for a full understanding

149 Rwanda adhered to the WIPO Convention by Law no. 16/1983 of 18/08/1983(OGRR, 1983, p. 667). The instrument was signed at Stockholm on 14 July 1967 and entered into force in 1970 and was amended in 1979.

150 The objectives of the Organisation, as enshrined in Article III of the Lusaka Agreement, show that, cooperation in industrial property is intended to achieve technological advancement for economic and industrial development of the member states. Details on ARIPO are available at www.aripo.org.

151 Art. 189, al.2 of the Constitution of the Republic of Rwanda, OGRR, Year 42, special no, June $04^{\text {th }}, 2003$. See also Art. 190.

152 Loi no 06/1988 du 12 février 1988 portant Organisation des Sociétés Commerciales (Official Gazette, 1988, p. 437), also found in Codes et Lois du Rwanda, $2^{\text {nd }}$ edn (1995), Vol. 1, pp.352-73. See articles 32 to 38 .

153 D. P. Chiwandamira and D. Kemannzi, Analysis of Legal Aspects of Local Pharmaceutical Production in Rwanda. A study commissioned by Federal Ministry for Economic Co-operation and Development (2006).

154 Loi du 25 février 1963 sur les brevets (Official Gazette, 1963, p.148) also found in Codes et Lois du Rwanda, $2^{\text {nd }}$ edn, V.III, pp. 1564-6.

155 Arrêté Ministériel no 5/10/67 du 5/10/1967 portant mesures d'exécution de la Loi sur les Brevets (Official Gazette, 1967, p. 214). 
of the invention, and a summary detailing in a precise manner what constitutes the novelty or originality of the invention. ${ }^{156}$

\section{WHY THE DEAL STALLED: THE BUREAUCRATIC FETTERS WITHIN THE WTO DECISION AND THE CAMR}

The notification of the WTO was the first in several steps that had to be taken before the affordable drugs reach patients in Rwanda. This is because, first, Apotex had to acquire a licence to produce the medicine Rwanda wants to import. This meant negotiations with nine patent holders. Fixed-dose medications, which combine multiple drugs in a single pill, make treatment regimes simpler and thus easier to expand to more patients. When Apotex agreed to produce the ARV in the fixed-dose combination (FDC), a first line drug, it was not listed as a product eligible for compulsory licensing for export in Schedule 1 of the Patents Act. ${ }^{157}$ In order to add this drug to the list, a decision of the Federal Cabinet is required, following the recommendation of both the Minister of Industry and the Minister of Health. After pressure, the Cabinet made the requisite order amending the Schedule to include TriAvir. The application was then submitted to Health Canada for approval. This process took 7 months. Further, TriAvir is a fixed-dose combination of the patented ARVdrugs zidovudine, lamivudine, and nevirapine. Patents on the components are held by GlaxoSmithKline and German-based Boehringer Ingelheim. ${ }^{158}$ GlaxoSmithKline, Shire and Boehringer Ingelheim each put forward numerous conditiond for issuing a voluntary licence. In the end, Glasko-SmithKline and Shire did not oppose the application, but chose not to grant a voluntary licence. This then required Apotex to make an application under Canada's Acess to Medicines Regime. Boehringer Ingelheim was also reticent to freely grant a licence. It was only after gaining regulatory approval of Health Canada that Apotex obtained a compulsory licence in 2007 to export the triple combination HIV/AIDS drug to Rwanda. ${ }^{159}$

Other requirements under the 30 August Decision include: specifications relating to name and address of the licensee, the product(s) for which the licence has been granted, the country or countries to which the product(s) is (are) to be supplied and the duration of the licence. Also, the address of the website of which the licensee posts its required notifications has to be provided. ${ }^{160}$ The Decision also requires special branding and packaging labels for drugs produced for export under the Decision to prevent diversion of goods. Clearly, there are so many superfluous rigours to go past before the deal can kick off.

156 Chiwandamira et al., supra note 153, p. 18.

157 RSC 1985.

158 GlaxoSmithKline held several relevant patents (including Canada Patent Nos 2,068,790, 2,070,230, 2,286,126 and 2, 311,988). The Boehringer Ingelheim Pharmaceuticals Inc. held the Canada Patent No. 2, 030,056.

159 Rimmer, supra note 119 , p. 93.

16030 August Decision, supra note 111, para 2 (c ). See also Shashikant, supra note 118. 
The stringency of the August 30 Decision naturally gave birth to a rigid Canadian law. The Regime is fettered by rigours and needs remedying. ${ }^{161}$ About the CAMR, Richard Elliott identifies that there is a need to eliminate limits on the products that are subject to compulsory licensing because currently, the legislative provisions constituting the CAMR include a limited list of pharmaceutical products, consisting primarily of drugs on the WHO's Model List of Essential Medicines plus most of the other ARV drugs then under patent in Canada. ${ }^{162}$ Further, the mechanism also bears discriminatory aspects in that it has doublestandards against non-WTO countries. ${ }^{163}$ The CAMR takes all 'least developed countries' and all developing countries belonging to the WTO as potentially eligible importers of Canadian-made generics. It however creates unjustifiable hurdles for developing countries that are not members of the WTO and that are not 'least developed countries'. Thus, in order to be added to the list of eligible importers of Canadian-made generics, a non-WTO developing country must declare 'an emergency or other circumstances of extreme urgency, and must also agree that the imported product will not be used for 'commercial purposes' - a vague and undefined term capable of being interpreted as interference with distribution of the product in the importing country through private, for-profit pharmacies. ${ }^{164}$

Another intrinsic barrier within the Canadian law relates to non-governmental organisations (NGO) procurement. The law requires that an NGO purchasing Canadian-made generics for importation into an eligible country must have the 'permission' of the country. 'Permission' is not defined. ${ }^{165}$ Rather, it is suggested that the importing countries should be notified by the Government of Canada of any application under the CAMR system made on their behalf. ${ }^{166}$ In this regard, it is argued that if a scenario ever arises that an NGO is able and actively seeking to access the CAMR system on behalf of an importing country and, that importing country government objects to these actions, the importing country government could challenge this application with its own application to the CAMR or with notification of its intentions to apply to the CAMR ${ }^{167}$ Given the pivotal role that NGOs play in many low and middle income countries, this provision becomes

161 See R. Elliot, 'Delivery Past Due: Global Precedent set under Canada's Access to Medicines Regime', 13 (1) HIV/AIDS Policy \& Law Review (2008): 7. K. R. Sirinivas, 'Interpreting Paragraph 6 Deal on Patents and Access to Treatment', Economic and Political Weekly, 20 September 2003; J. Love, 'CPTech Statement on WTO Deal on Exports of Medicines' (30 August 2003), available at www.cptech.org/ip/wto/ptech08302003.html (accessed 19 July 2008).

162 See Canada's Patent Act, Schedule 1, at http://laws.justice.gc.ca/en/showdoc/cs/P-4/sc:1// en\#anchorsc: 1 .

163 Elliot, supra note 161, p 7.

164 Ibid.

165 Elliot, supra note 161, p. 8.

166 A report by The AIDS in Africa Working Group and Access to Drugs Initiative entitled 'Making Canada's Access to Medicines Regime Work for Countries in Need: A Case Study on Ghana'. University of Toronto, Faculty of Law, International Human Rights Program (January 2007), available at http://www.camr-rcam.gc.ca/review-reviser/camr_rcam_ut.stu_05-eng.pdf.

167 lbid. 
more restraining than enabling to NGOs seeking to urge governments to provide ARVs.

Other concerns raised in regard to the law are the rigorous requirement of Health Canada's approval as the only acceptable one. There is also the requirement of advance disclosure of the importing country, which may result in pressures from the patent holders and any government against the use of compulsory licensing; negotiations for voluntary licences in urgent situations, arbitrary twoyear time limit on compulsory licences; issues relating to option for re-exportation from importing country within regional trading bloc and extra opportunities for ligation by patent holders. ${ }^{168}$ The Canadian law is also out of touch with realities of international drug procurement regimes relating to a public tendering process. This increases the gulf between manufacturers of drug products and the international funding required to pay for medicines. ${ }^{169}$ Further, the CAMR espouses an unnecessary provision which is inhibitive to a Canadian company wishing to apply for a licence as it requires a licence applicant to specify 'the name of the government person or entity, or the person or entity permitted by the government of the importing country, to which the product is to be sold, and prescribed information, if any, concerning that person or entity. ${ }^{170}$ Experiences of Brazil, South Africa and Thailand show that this simply opens up the importing entity to attack from antagonists of compulsory licences. This may even be worse for a least developed country.

\section{RECOMMENDATIONS AND ISSUES FOR CONSIDERATION}

The protracted struggle to make use of the CAMR points to some critical issues for consideration with regard to developing countries accessing ARV drugs from developed countries. Some of the questions and issues therein are: Is the WTO General Council Decision a solution? Are developing countries doing enough to make it easier for developed countries to import drugs from their jurisdictions? Are pharmaceutical companies honouring their TRIPS obligations in terms of human rights and public health? Are African governments doing enough to take advantage of the TRIPS regime? Are African governments exploring other avenues and addressing the intricate barriers? Can we move past market dominance?

The first application of the mechanism shows that it is too cumbersome to work effectively. Considering that developed countries are under the obligation to assist developing countries in technology and skills transfer under the Doha Declaration, ${ }^{171}$ it has been argued that there are better opportunities for developing countries to scale up treatment for their citizens if they are allowed to effectively invoke the flexibility provisions contained in the TRIPS Agreement, particularly

168 Elliot, supra note 161, p. 9.

169 For further shortcomings of the CAMR, see Elliot, supra note 161.

170 See section 21.04(2) (f) of the CAMR.

171 See para 7. 
compulsory licensing. But with limited resources and high cost of drugs, particularly for second-line drugs for HIV/AIDS treatment, only a few can be accessed. There have been suggestions that the CAMR needs to be reformed to cater for standard international procurement methods, which are considered to be more objective, transparent, and efficient than direct negotiation. This would bring it in tune with the WTO's interagency Guidelines, accepted by the Global Fund. ${ }^{172}$ Elliot ${ }^{173}$ and Rimmer ${ }^{174}$ have also suggested areas of reform in this regard. The process proved cumbersome and the generic manufacturer has few incentives to go through with it. It is economically imprudent to produce for merely one importing country, and it is difficult to convince countries to notify the WTO of their need to import. Additionally, Canada imposes a maximum term of two years for the compulsory license, not enough to recoup the investment for producing a generic drug. The mechanisms are not commensurate to the need and defy expediency.

The alternative has also been entertained that Rwanda could have imported a similar combination drug from India, also known as the 'pharmacy of the poor', which is available at $\$ 0.14$ per tablet ${ }^{175}$ and not yet affected by India's new patent legislation. ${ }^{176}$ India supplies about half the generic drugs in Africa. ${ }^{177}$ If this was the case, Rwanda would only have had to impose a compulsory license in its own territory, and possibly not even need this step, as it is not clear whether any of the nine inventions have been patented in Rwanda. Apotex itself concluded that the mechanism would have to be changed to work effectively. ${ }^{178}$

In order for developing countries to take advantage of the TRIPS flexibilities, the first step is that they should adopt a legal and policy framework that allows for compulsory licensing and limited exceptions. The advantage is that these flexibilities, together with the provisions of the Doha Declaration, are self executing and need to be domesticated. If sub Saharan African countries have to benefit from the process, efforts must be galvanized to bring patent laws up to standard to meet the demand. This will require political enthusiasm and legal and judicial activism. Countries like Brazil, India and Thailand had to go through worse times to reap the benefit. Hiding heads in the sand by African states for fear of sanctions is a disservice because the need for ARVs is not retreating; neither is the epidemic showing signs of abating.

172 Guide to the Global Fund's Policies on Procurement and Supply Management, available at http://www.theglobalfund.org/pdf/guidelines/pp_guidelines_procurement_supplymanagement_ en.pf.

173 Elliott, supra note 161.

174 Rimmer, supra note 2.

175 A. Attaran, 'AIDS Drugs Fiasco a Tale of Red Tape', Toronta Star (9 August 2007). Rwanda had in the past imported low-cost medicines from India and Brazil.

176 Chan Park of the Lawyers Collective HIV/AIDS Unit in India, available at http://www.cptech. org/ip/health/c/india/.

177 Guardian Unlimited ( Special Reports), 'Cheap AIDS Drugs under Threat', available at www.guardian .co.uk/aids/story/0,7369,00.html (accessed 20 August 2008).

178 Apotex, Life Saving AIDS Drug for Africa Gets Final Clearance, Press Release (21 September 2007). 
Other suggestions include: a 'one-licence solution' strategy which authorises a generic company with a single licence to multiple countries, without requiring advance notification, pre-determined quantities of the product, and a separate country for each single drug order. Local manufacturing has also been suggested if human and technological capacity is scaled up. A cost-benefit analysis should be done by most countries considering local production and more aggressive technology transfer. Other measures include administrative, knowledge and other existing barriers should also be addressed through obtaining support from developed countries and/or international organisations on the effective implementation of compulsory licensing. Policy reform in the area of tax, tariff and mark-ups to determine what changes could facilitate more affordable prices for the population has also been suggested. All policy choices must be informed by local circumstances and context.

\section{CONCLUSION}

Expediency is core to accessibility and availability of drugs within the context of the right to health. ${ }^{179}$ Both the WTO Decision and the CAMR are not offering solutions so far. Clearly, the Rwanda-Apotex deal cast doubt on the efficacy of the WTO General Council Decision. It is little wonder that it has been described as 'a gift bound in red tape'. ${ }^{180}$ The MSF described the WTO system as 'neither expeditious, nor a solution'. ${ }^{181}$ The deal also reeks of the influence of neoliberalism and market economies. Like Richard Elliott observed: 'The market does not respond to the needs of poor people... they are not a big draw for pharmaceutical producers because they don't have money'. ${ }^{182}$ Given the defects of the mechanism, the Director General of the European Generic Medicines Association concluded at a hearing of the European Parliament that it is unlikely that any company in Europe would make use of the mechanism. ${ }^{183}$ It is therefore imprudent for WTO and its mechanism to talk about 'public goods' problems with a 'private market' solution. ${ }^{184}$ The TRIPS largely entrenched a system of market

179 See CESCR General Comment 3 (para 2) on the nature of state obligations (art. 2 of the Covenant). It explains that steps have to be within a reasonably short time; C. Corea, 'Recent International Developments in the Area of Intellectual Property Rights', ICSTD-UNCTD Dialogue, $2^{\text {nd }}$ Bellagio Series on Development and Intellectual Property, 18-21 September 2003.

180 See 'Joint NGO Statement on TRIPS and Public Health WTO Deal on Medicines: A "gift" Bound in Red Tape' (10 September 2003), available at http://www.cptech.org/ip/wto/p6/ ngos09102003.html.

181 Médecins Sans Frontières, Neither Expeditious, nor a Solution: The WTO August 3oth Decision is Unworkable, available at http:/www.msf.ch/fileadmin/user_upload/uploads/communiques/ images_2006/pdf/came_Neither_expeditious_nor_a_solution_-_August_30_and_the_JCPA_ single_page.pdf.

182 A. Silversides, 'Not a Single Pill', Ottawa Citizen, 13 August 2006.

183 Presentation by Greg Perry to the European Parliament's Mini-Hearing on TRIPS and Access to Medicines, 5 July 2007, Brussels.

184 F. M. Abbott and J. H. Reichman, 'Strategies for the Protection and Promotion of Public Health Arising Out of the WTO TRIPS Agreement Amendment Process', available at http://www.who.int/phi/public_hearings/second/contributions_section1/Section1_ Abbott\&Reichman.pdf. 
dominance and sheer protectionism. The rigours of the WTO Decision led Love to conclude that it is an endorsement of a new model of explicit protectionism:

The U.S, Europe, Canada, Australia, Japan and other developed economies will be allowed to bar imports from developing country generic suppliers - under completely irrational protectionist measures that are defended by the WTO Secretariat and its most powerful members as a humanitarian gesture. ${ }^{185}$

It would be safe to conclude that the lack of expedition accompanying the Rwanda-Apotex deal points to a few things: developing countries are yet to grow under the TRIPS and its system; developed countries are not necessarily keen on the transfer of technology to developing countries, the manufacture, production and availability of ARVs is still left to the mercy of market forces as influenced by neo-liberal trends with the result that drugs are still largely unaffordable and inaccessible. The transition period may as well have to be further extended, or the requirement of protection of pharmaceuticals done away with altogether as suggested that a moratorium be set on further intellectual property standard setting exercise in order to give the incipient transnational system of innovation, triggered by TRIPS, time to breathe and grow. ${ }^{186} \mathrm{~A}$ recent report ${ }^{187}$ shows that Apotex has undertaken to ship seven million antiretroviral pills to Rwanda to treat 21,000 patients for one year but added that it will not participate in the program in the future unless the government corrects the law to alleviate some of the problems with its implementation. Bruce Clark, vice president of Apotex's regulatory and medical affairs, said that the law is 'laborious and convoluted' and that it is 'almost a waste for us to go through the process. ${ }^{188}$ If developed countries are really committed to the goal of universal access to AIDS drugs, then less laborious mechanisms should be put in place. It is imperative that G8 countries embark on practical means to achieve what they committed to in the World Summit the 2010 Global Target on Universal Access for HIV/AIDS treatment, prevention, care and support. ${ }^{189}$ This was also reiterated in the recent XVII International AIDS Conference in Mexico. ${ }^{190}$

185 Love, supra note 161.

186 K. E. Maskus and J. H. Reichman, 'The Globalization of Private Knowledge Goods and the Privatisation of Global Public Goods', 7 Journal of International Economic Law (2004): 279-320.

187 Kaiser Daily HIV/AIDS Report 'Complexity of Canadian Law Hindering Shipments of Generic Antiretrovirals to Developing Countries, Company Says' (24 September 2008), available at http://www.kaisernetwork.org/daily_reports/rep_index.cfm?hint=1\&DR_ID=54620.

188 Ibid.

189 Canada, France, Germany, Italy, Japan, Russia, the UK and the US pledged to ensure universal access to antiretroviral treatment worldwide by 2010 . See details in Outcome Document from the 2005 World Summit, 15 September.

190 The XVII International AIDS Conference was held in Mexico from 3 to 8 August 2008. 